DOI: 10.32844/2222-5374-2020-104-2.22

УДК: 342.9

Кошиков Д. О., старший викладач кафедри поліщейської діяльності та публічного адміністрування Харківського національного університету внутрішніх справ, кандидат юридичних наук

\title{
ГАРАНТІЇ ПРАВ УЧАСНИКІВ АДМІНІСТРАТИВНО-ПРАВОВИХ ВІДНОСИН У СФЕРІ РЕАЛІЗАЦІЇ ДЕРЖАВНОЇ ПОЛІТИКИ У СФЕРІ ЗАБЕЗПЕЧЕННЯ ЕКОНОМІЧНОЇ БЕЗПЕКИ ДЕРЖАВИ
}

Актуальність статті полягає в тому, що норми права регулюють майже всі сфери суспільного життя, в тому числі закріплюють основоположні права і свободи, що виникають у осіб у зв'язку з їх участю у різних видах правовідносин. В контексті викладеного сфера реалізації державної політики у сфері забезпечення економічної безпеки держави не $\epsilon$ виключенням, з огляду на те, що механізм забезпечення адміністративноправових відносин, що функціонує в цій сфері, включає власні специфічні гарантії. Саме останні забезпечують стабільний розвиток адміністративно-правових відносин у сфері реалізації державної політики у сфері забезпечення економічної безпеки держави, а тому їх встановлення $\epsilon$ обов'язковим компонентом державної політики в зазначеній сфері. Зазначено, що правові гарантії набувають специфічних рис в залежності від виду правовідносин, учасниками яких є відповідні суб'єкти, а також від сфери, в якій такі правовідносини виникають. У зв'язку з чим виокремлено ознаки адміністративно-правових відносин щодо реалізації державної політики у сфері забезпечення економічної безпеки держави. Під гарантіями прав учасників адміністративно-правових відносин щодо реалізації державної політики у сфері забезпечення економічної безпеки держави запропоновано розуміти сукупність нормативно-закріплених положень, що забезпечують можливість уповноважених суб'єктів, які вступають у адміністративноправові відносини в сфері забезпечення економічної безпеки держави, зокрема з приводу формування та реалізації державної політики, охороняти та захищативласні права та безперешкодноздійснювати професійнудіяльність, отримувати належне матеріально-технічне забезпечення, приймати нормативні та управлінські рішення; здійснювати заходи організаційного характеру та звертатися за захистом свої прав до суду.

Запропонованокласифікаціюгарантійправучасниківадміністративноправових відносин щодо реалізації державної політики у сфері забезпечення економічної безпеки держави за такими критеріями:

- сферою дії: загальні, якими користуються всі без виключення учасники вказаних правовідносин, і спеціальні, які характерні для окремих суб'єктів (прийняття обов'язкових до виконання рішень, незалежність при здійсненні власної професійної діяльності та прийняття рішень тощо); 
- в залежності від суб'єкта, якому належить така гарантія: гарантії прав вищих органів державної влади, центральних органів виконавчої влади, органів місцевого самоврядування, інституцій громадянського суспільства;

-змістом (характером) юридичних гарантій: а) нормативні; б) організаційні; в) матеріально-технічні; г) правоохоронні.

Ключові слова: економічна безпека, національна безпека, державна політика, адміністративно-правові засади, суб'єкти, адміністративне законодавство, гарантії, адміністративно-правові відносини, оптимізація, удосконалення.

Актуальність теми. Норми права регулюють майже всі сфери суспільного життя (як службові, так і особисті), в тому числі закріплюють основоположні права і свободи, що виникають у осіб у зв'язку з їх участю у різних видах правовідносин. В контексті викладеного сфера реалізації державної політики у сфері забезпечення економічної безпеки держави не $\epsilon$ виключенням, з огляду на те, що механізм забезпечення адміністративно-правових відносин, що функціонує в цій сфері, включає власні специфічні гарантії. Саме останні забезпечують стабільний розвиток адміністративно-правових відносин у сфері реалізації державної політики у сфері забезпечення економічної безпеки держави, а тому їх встановлення $\epsilon$ обов'язковим компонентом державної політики в зазначеній сфері. Слід відзначити, що всупереч значущості встановлення та забезпечення функціонування гарантій прав учасників адміністративно-правових відносин у сфері реалізації державної політики у сфері забезпечення економічної безпеки держави, вони залишились поза увагою науки адміністративного права. На нашу думку, таку наукову прогалину можна пояснити браком автономії сфери економічної безпеки держави, що частіше розглядається лише як окремий вид національної безпеки. Відповідно, гарантії прав учасників останньої по аналогії, переважно визначаються як складові гарантій сфери національної безпеки держави.

Виклад основного матеріалу. Перш ніж перейти безпосередньо до визначення прав учасників адміністративно-правових відносин у сфері реалізації державної політики у сфері забезпечення економічної безпеки держави, вважаємо за необхідне в даному підрозділі дисертаційного дослідження: по-перше, з'ясувати зміст юридичної категорії «гарантії прав особи»; по-друге, охарактеризувати сутність адміністративно-правових відносин, які виникають внаслідок реалізації державної політики у сфері забезпечення економічної безпеки держави; по-третє, сформувати уявлення про види та зміст гарантій прав учасників цих відносин за допомогою застосування методу індукції та інших загальних і спеціальних методів наукового пізнання.

У тлумачних словниках знаходимо наступні значення слова гарантія: 1) «порука, забезпечення, застава, умови, що забезпечує що-небудь.» [1, c. 344]; 2) «запорука виконання зобов'язань, здійснення прав» [2, с. 173]; 3) «надання чи створення матеріальних засобів; охорону кого, чого-небудь від небезпеки; гарантування чогось» [3, с. 42]. Як вбачається, слово гарантія пов'язане з процесами забезпечення та охорони, а їх існування саме по собі забезпечує захист об'єкту, щодо якого вони встановлені. 
В юриспруденції такі тлумачення отримали дещо інше забарвлення, зокрема в навчально-методичних розробках і у роботах монографічного характеру, де досліджувались правові гарантії. Так, у юридичному словнику термін правові гарантії отримав таке визначення: «закріплені в юридичних нормах правові засоби, які безпосередньо спрямовані на забезпечення правомірної поведінки учасників будь-яких суспільних відносин або нормального функціонування того чи іншого інституту» [4, c. 132]. Схоже розширене визначення гарантій в правовій сфері використовує О.В. Мазур, зазначаючи, що в такому разі вони включають усі чинники та фактори, котрі стосуються забезпечення безперешкодної реалізації прав, свобод і законних інтересів громадян, а також нейтралізації причин і умов їх порушень [5, с. 129].

Отже, гарантії являють собою певні засоби, що отримали законодавче закріплення в конкретних нормах права, за допомогою яких охороняються права, свободи та законні інтересі осіб, в тому числі тих, що виникають внаслідок участі в тих чи інших правовідносинах. У свою чергу, необхідно акцентувати увагу на обов'язковому законодавчому закріпленні таких гарантій, адже сама така умова забезпечує їх існування, функціонування, стабільність і дієвість.

Виходячи з усього наведеного можна зробити наступні проміжні висновки щодо гарантій як юридичної категорії: по-перше, гарантії - це обов'язковий елемент, який утворюють сукупність об'єктів, спрямованих на забезпечення та охорону основоположних цінностей - прав і свобод; по-друге, вони завжди пов'язані з конкретною особою та її правовим статусом; по-третє, зміст гарантій може змінюватись в залежності від видів правового статусу особи та тих відносин, учасником яких вона стає; по-четверте, хоча основною метою встановлення гарантій і $€$ забезпечення та захист прав і свобод особи, що відображається в їх охоронній і забезпечувальній функціях, вони також виконують ще одну - превентивну функцію; по-п'яте, в механізмі забезпечення прав і свобод людини вони стають динамічними за умови настання певних факторів, наприклад, посягання чи порушення прав і свобод, до цього моменту вони перебувають у статистичному стані; по-шосте, гарантії повинні мати законодавче закріплення для того, що б виконувати свої функції, в противному випадку вони втрачають юридичні властивості та не можуть у повному обсязі виконувати власні функції; по-сьоме, для функціонування гарантій не потрібно наявність або створення будь-яких спеціальних правових умов, оскільки воно забезпечується всією системою права.

Загальні правові гарантії особи набувають специфічних рис в залежності від виду правовідносин, учасниками яких являються особи, а також від сфери, в якій такі правовідносини виникають.

Необхідно враховувати, що будь-які гарантії суб'єктів у зазначеній сфері містяться в чинному законодавстві, тобто мають законодавче закріплення, разом із тим вони не упорядковані і розосереджені в різних законах і підзаконних нормативно-правових актах, а тому для їх систематизації в науковій літературі часто проводиться класифікація. Такий самий прийом застосовувався для визначення гарантій прав i суб'єктів у різних правовідносинах. Основною класифікацією гарантій 
$€$ їх поділ на загальні та спеціальні: перші об’єднують соціальний, економічний, політичний і ідеологічний види гарантій, а спеціальними позначаються виключно юридичні [6, с. 202; 7, с. 99]. Зустрічаються й інші класифікації, наприклад О.В. Снежко пропонує поділяти гарантії за сферою дії на національні та міжнародні гарантії [8, с. 202]. 0.Ф. Скакун пропонує розрізняти юридичні гарантії прав і свобод людини за критерієм: форм забезпечення (гарантії реалізації, охорони та захисту) [9, с. 75], а юридичні гарантії правової законності на - юридичні умови, правові способи та організаційно-правові засоби [9, с. 497].

У вузькопрофільних дослідженнях щодо визначення змісту юридичних гарантій їх класифікація проводиться більш грунтовно. Так, В.М. Довжанин класифікує гарантії адміністративно-правового забезпечення прав і свобод громадян у сфері запобігання та протидії корупції на: загальні (економічні, політичні, ідеологічні, соціальні) та спеціальні або юридичні гарантії. В свою чергу, юридичні гарантії було поділено на: нормативні, інституційно-організаційні та організаційно-правові гарантії [7, с. 99-100]. М.М. Войнарівський для класифікації господарсько-правових гарантій у системі правових гарантій обрав: 1) критерій функціонального призначення (гарантії реалізації, охорони, захисту та відновлення субıєктивних прав та законних інтересів); 2) критерій типу правових норм-гарантій (матеріально-правові та процесуально-правові гарантіі); 3) «за критерієм учасника господарських правовідносин, право якого гарантується, на: гарантії прав субґєктів господарювання, споживачів, органів державної влади та місцевого самоврядування, громадян та організацій, які виступають засновниками суб〉єктів господарювання чи здійснюють щодо них організаційногосподарські повноваження на основі відносин власності» [10, с. 7].

Переважна більшість гарантій прав учасників адміністративноправових відносин у сфері реалізації державної політики у сфері забезпечення економічної безпеки держави зводиться до: 1) прийняття обов'язкових до виконання рішень (вищі органи державної влади, центральні органи виконавчої влади, органи місцевого самоврядування); 2) незалежності при здійсненні власної професійної діяльності та прийняття рішень (суди, прокуратура, органи місцевого самоврядування); 3) отримання інформації, що стосується стану економічної безпеки у випадках, якщо не встановлено спеціальних режимів її використання чи поширення (органи місцевого самоврядування, громадські інституції); 4) належного рівня матеріально-технічного забезпечення функціонування окремих суб'єктів, які реалізують державну політику в сфері забезпечення економічної безпеки держави, систематичної оплати праці посадових осіб таких суб'єктів і здійснення їх соціального захисту (вищі органи державної влади, центральні органи виконавчої влади, органи місцевого самоврядування); 5) проведення громадської експертизи правових актів, участь в їх обговоренні, в тому числі під час парламентських слухань, подання до них своїх висновків і пропозицій (інституції громадянського суспільства); 6) права на звернення до Уповноваженого Верховної Ради України з прав людини у випадку, якщо права, свободи та інтереси учасників цих правовідносин порушено діяннями суб'єктів, що 
забезпечують економічну безпеку держави (інституції громадянського суспільства); 7) обов'язку нести юридичну відповідальність у випадку здійснення посягання на економічну безпеку держави, коли один із учасників цих правовідносин своїми діями чи бездіяльністю завдає шкоду іншому (вищі органи державної влади, центральні органи виконавчої влади, органи місцевого самоврядування, інституції громадянського суспільства); 8) можливості звернутися до суду у тому разі, коли порушено або існує імовірність порушення їх прав, свобод і інтересів у сфері економічної безпеки держави (вищі органи державної влади, центральні органи виконавчої влади, органи місцевого самоврядування, громадські інституції); 9) залучення до формування економічної політики держави, підготовки стратегічно важливих нормативно-правових актів у сфері економічної безпеки держави, зокрема проекту Стратегії національної безпеки України (вищі органи державної влади, центральні органи виконавчої влади, органи місцевого самоврядування, громадські інституції).

Зважаючи на множинність учасників адміністративно-правових відносин у сфері реалізації державної політики у сфері забезпечення економічної безпеки держави та відмінний зміст гарантій їх прав, вважаємо за доцільне здійснити класифікацію таких юридичних гарантій за наступними критеріями:

- сферою дії: загальні, якими користуються всі без виключення учасники вказаних правовідносин (наприклад, обов'язок нести юридичну відповідальність у випадку здійснення посягання на економічну безпеку держави чи у випадках, коли економічній безпеці діями чи бездіяльністю суб'єкта завдано шкоду) і спеціальні, що характерні для окремих суб'єктів (прийняття обов'язкових до виконання рішень, незалежність при здійсненні власної професійної діяльності та прийняття рішень тощо);

- в залежності від суб'єкта, якому належить така гарантія: гарантії прав вищих органів державної влади; гарантії прав центральних органів виконавчої влади; гарантії прав органів місцевого самоврядування; гарантії прав інституцій громадянського суспільства;

- змістом (характером) юридичних гарантій: нормативні (прийняття обов'язкових до виконання рішень, проведення громадської експертизи правових актів, участь в їх обговоренні, в тому числі під час парламентських слухань, подання до них своїх висновків і пропозицій); організаційні (незалежність при здійсненні власної професійної діяльності та прийнятті рішень; отримання інформації, що стосується стану економічної безпеки у випадках, якщо щодо неї не встановлено спеціальних режимів її використання чи поширення, залучення до формування економічної політики держави, підготовки стратегічно важливих нормативно-правових актів у сфері економічної безпеки держави, зокрема проекту Стратегії національної безпеки України); матеріально-технічні (належний рівень матеріально-технічного забезпечення функціонування окремих суб'єктів реалізації державної політики у сфері забезпечення економічної безпеки держави, систематична оплати праці посадових осіб таких суб'єктів і здійснення їх соціального захисту); правоохоронні (право на звернення до Уповноваженого Верховної Ради України з прав людини у випадку, якщо їх права, свободи та інтереси порушено діяннями суб'єктів, 
що забезпечують економічну безпеку держави; обов'язок нести юридичну відповідальність у випадку здійснення посягання на економічну безпеку держави чи у випадках, коли останній своєю дією чи бездіяльністю суб'єкта завдано шкоду; можливість звернутися до суду у випадку, коли порушено чи $є$ імовірність порушення їх прав, свобод і інтересів у сфері економічної безпеки держави).

На підставі систематизації гарантій прав учасників адміністративноправових відносин у сфері реалізації державної політики у сфері забезпечення економічної безпеки держави та проведеної класифікації можемо виокремити такі ознаки вказаних гарантій: а) є інструментом, за допомогою якого забезпечуються та охороняються права, свободи та інтереси учасників адміністративно-правових відносин щодо реалізації державної політики у сфері забезпечення економічної безпеки держави; б) функціонування гарантій забезпечується всією системою права, зокрема дією інших правових механізмів, наприклад механізму притягнення до юридичної відповідальності; в) обсяг гарантій і їх зміст залежить від суб'єкта, якому вони притаманні, він також може змінюватись залежно від конкретних адміністративно-правових відносин, учасником яких $\epsilon$ такий суб'єкт; г) існують загальні та спеціальні гарантії (першими користуються всі без виключення учасники вказаних правовідносин, а другими - окремі учасники адміністративно-правових відносин щодо реалізації державної політики у сфері забезпечення економічної безпеки держави); ґ) виконують охоронну, забезпечувальну та превентивну функції; д) мають обов'язкове законодавче закріплення, тобто містяться в приписах чинного законодавства, переважно у законах і підзаконних нормативно-правових актах, що регулюють діяльність учасників адміністративно-правових відносин щодо реалізації державної політики у сфері забезпечення економічної безпеки держави; е) можуть мати нормативний, організаційний, матеріально-технічний чи правоохоронний характер.

Отже, під гарантіями прав учасників адміністративно-правових відносин щодо реалізації державної політики у сфері забезпечення економічної безпеки держави необхідно розуміти сукупність нормативнозакріплених положень, що забезпечують можливість вищих органів державної влади, центральних органів виконавчої влади, органів місцевого самоврядування та інституцій громадянського суспільства, які вступають в адміністративно-правові відносини щодо забезпечення економічної безпеки держави, зокрема з приводу формування та реалізації державної політики, охороняти та захищати власні права та безперешкодно здійснювати професійну діяльність, отримувати належне матеріальнотехнічне забезпечення, приймати нормативні та управлінські рішення; здійснювати заходи організаційного характеру та звертатися за захистом своїх прав до суду.

Слід підкреслити, що визначені вище гарантії прав учасників адміністративно-правових відносин щодо реалізації державної політики у сфері забезпечення економічної безпеки держави не претендують на догматичність, оскільки можуть бути розкриті більш детально щодо кожного окремого суб'єкта, що є учасником таких правовідносин. Разом 
iз тим їх окреслення сприятиме формуванню уявлення про них як про цілісну уніфіковану систему, що в перспективі може отримати подальше вдосконалення, як в науці адміністративного, так i в нормотворчій діяльності, а також може бути використана під час вироблення окремої стратегії державної політики у сфері забезпечення економічної безпеки держави та відповідного плану заходів.

\section{СПИСОК ВИКОРИСТАНИХ ДЖЕРЕЛ}

1. Даль В. И. Толковый словарь живого великорусского языка: в 4 т. М.: Гос. изд. иностр. и нац. словарей, 1956. Т. 1. 699 с.

2. Бусел В.Т. Великий тлумачний словник сучасної української мови. К.; Ірпінь: Перун, 2002. 1440 с.

3. Новий тлумачний словник української мови: у 4 т. К.: Аконіт, 2000. T. 2.912 c.

4. Бабій Б. М., Бурчак Ф. Г., Корецький В. М., Цветков В. В. Юридичний словник. К.: УРЕ, 1983. 872 с.

5. Мазур 0. В. Засоби забезпечення прав та законних інтересів підозрюваного: поняття і система. Науковий часопис Національної академії прокуратури України. 2017. № 4(16). С. 128-135.

6. Волинка К. Г. Теорія держави і права: навчальний посібник. К.: МАУП, 2003. 240 с.

7. Дожанин В. М. Класифікація гарантій адміністративно-правового забезпечення прав і свобод громадян у сфері запобігання та протидії корупції. Visegrad Journal on Human Rights. 2015. № 1. С. 98-106.

8. Снежко О. В. Конституционные основы государственной защиты прав и свобод человека и гражданина в Российской Федерации: дис. ... канд. юрид. наук : 12.00.02. Саратов, 1999. 195 с.

9. Скакун О. Ф. Теорія права і держави: підручник. К.: Алерта; КНТ; ЦУЛ, 2010. 520 с.

10. Войнарівський М. М. Гарантії прав та законних інтересів субьєктів господарювання при застосуванні адміністративно-господарських санкцій: автореф. дис ... канд. юрид. наук: 12.00.04. Одеса, 2014. 22 с.

\section{Koshykov}

\section{GUARANTEES OF THE RIGHTS OF PARTICIPANTS OF ADMINISTRATIVE AND LEGAL RELATIONS IN THE FIELD OF IMPLEMENTATION OF STATE POLICY IN THE FIELD OF ENSURING THE ECONOMIC SECURITY OF THE STATE}

The relevance of the article is that the rules of law regulate almost all spheres of public life, including the fundamental rights and freedoms that arise in individuals in connection with their participation in various types of legal relations. In the context of the above, the implementation of state policy in the field of economic security of the state is no exception, given that the mechanism of administrative and legal relations, which operates in this area, includes its own specific guarantees. It is the latter that ensure the stable development of administrative and legal relations in the field of implementation of state policy in the field of economic security of the 
state, and therefore their establishment is a mandatory component of state policy in this area. It is noted that legal guarantees acquire specific features depending on the type of legal relationship, the participants of which are the relevant entities, as well as the area in which such legal relations arise. In this regard, the signs of administrative and legal relations for the implementation of state policy in the field of economic security of the state. Under the guarantees of the rights of participants in administrative and legal relations to implement state policy in the field of economic security of the state, it is proposed to understand a set of normatively enshrined provisions that enable authorized entities entering into administrative and legal relations in the field of economic security of the state. on the formation and implementation of state policy, to protect and defend their rights and to carry out their professional activities without hindrance, to receive appropriate logistical support, to make regulatory and administrative decisions; carry out organizational measures and apply to the court for protection of their rights.

The classification of guarantees of the rights of participants of administrative and legal relations concerning realization of the state policy in the field of maintenance of economic safety of the state on the following criteria is offered:

- scope: general, which are used by all participants of these legal relations without exception, and special, which are characteristic of individual entities (making binding decisions, independence in carrying out their own professional activities and decision-making, etc.);

- depending on the entity to which the following guarantee belongs: guarantees of the rights of higher state authorities, central executive bodies, local self-government bodies, civil society institutions;

- the content (nature) of legal guarantees: a) regulatory; b) organizational; c) material and technical; d) law enforcement.

Keywords: economic security, national security, state policy, administrative and legal principles, subjects, administrative legislation, guarantees, administrative and legal relations, optimization, improvement. 